\title{
Polo-like Kinase 4 Inhibitor CFI-400945
}

\section{Fumarate}

National Cancer Institute

\section{Source}

National Cancer Institute. Polo-like Kinase 4 Inhibitor CFI-400945 Fumarate. NCI

Thesaurus. Code C111990.

An orally available fumarate salt form of CFI-400945, a polo-like kinase 4 (PLK4) inhibitor with potential antineoplastic activity. Upon oral administration, polo-like kinase 4 inhibitor CFI-400945 selectively inhibits PLK4, which results in the disruption of mitosis and the induction of apoptosis. PLK4 inhibition also prevents cell division and inhibits proliferation of PLK4-overexpressing tumor cells. PLK4, a member of the polo family of serine/threonine kinases overexpressed in a variety of cancer cell types, plays a crucial role in the regulation of centriole duplication during the cell cycle. 